This item was submitted to Loughborough's Research Repository by the author.

Items in Figshare are protected by copyright, with all rights reserved, unless otherwise indicated.

\title{
Rejecting the weak Asian body: boys visualising strong masculinities
}

\section{PLEASE CITE THE PUBLISHED VERSION}

http://www.routledge.com/books/details/9780415532778/

\section{PUBLISHER}

Routledge (@ the authors)

\section{VERSION}

SMUR (Submitted Manuscript Under Review)

\section{LICENCE}

CC BY-NC-ND 4.0

\section{REPOSITORY RECORD}

Hill, Joanne L.. 2019. "Rejecting the Weak Asian Body: Boys Visualising Strong Masculinities". figshare. https://hdl.handle.net/2134/11721. 
This item was submitted to Loughborough's Institutional Repository (https://dspace.lboro.ac.uk/) by the author and is made available under the following Creative Commons Licence conditions.

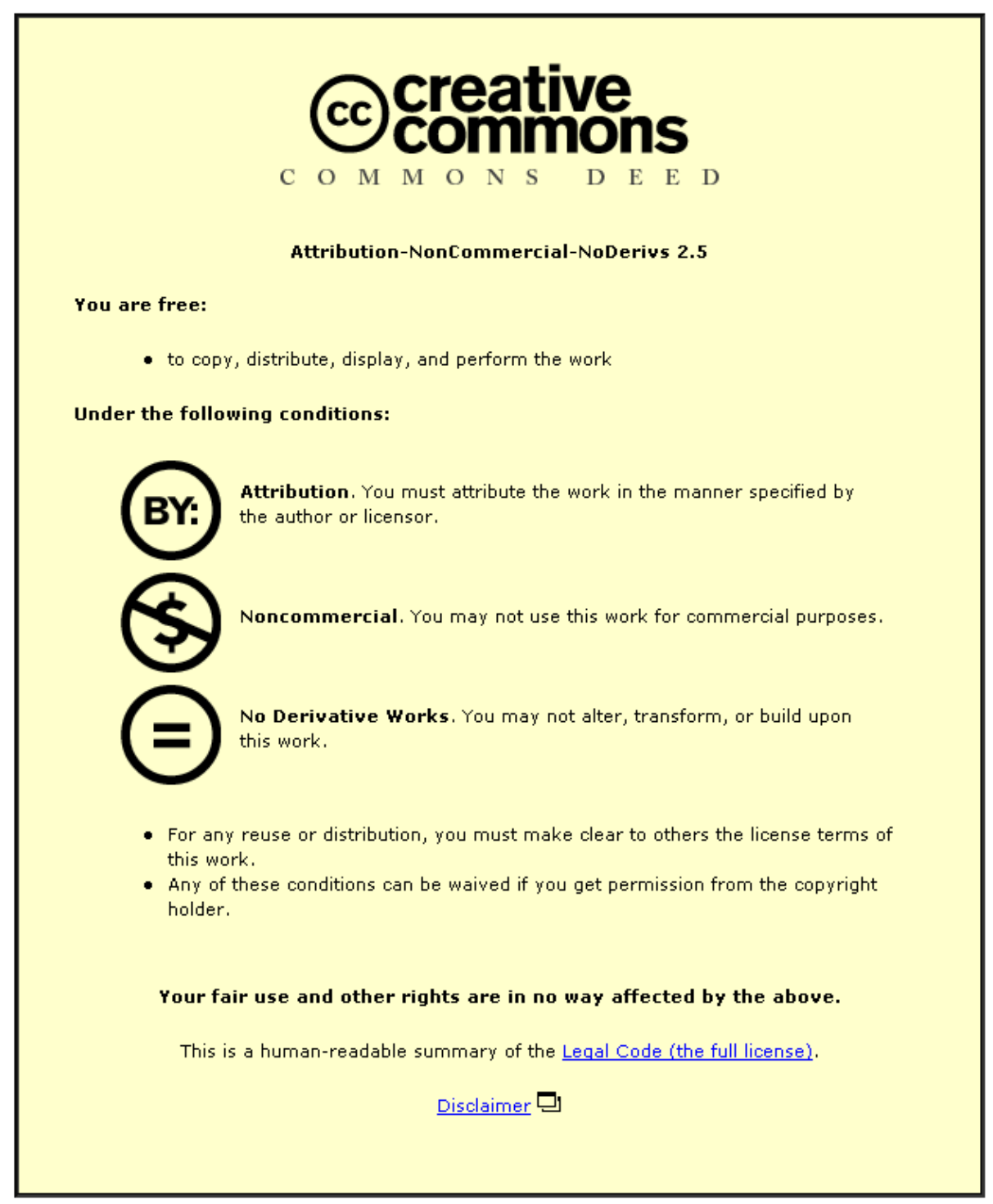

For the full text of this licence, please go to: http://creativecommons.org/licenses/by-nc-nd/2.5/ 


\section{Rejecting the weak Asian body: boys visualising strong masculinities}

\section{Joanne Hill}

This chapter draws on minority ethnic teenage boys' visual and verbal narratives of their physical activity experiences in and out of school. The purpose of this research is to explore boys' embodiment of racialised masculinities: to understand how boys negotiate dominant notions of masculinity as strength and muscularity in relation to local constructions of bodies among peers, in school and physical cultures, and in relation to their own embodied experiences. Drawing from focus-group interviews and participant-driven photography, using photo elicitation techniques, participants' photos served as a pedagogical forum for them to talk about, analyse, and reflect on their embodiment of masculinity in the physical culture relevant to their lives. This forms part of a larger visual ethnographic project that engaged young people in conversation and reflection on the bodies that are valued in PE and how they positioned themselves in relation.

\section{Background}

\section{Masculinity and sporting bodies}

Bodies are crucial in constructions of gender identities and PE is heavily implicated in what masculine bodies can be or how they can gain status over others. Status in secondary PE contexts is often associated with performances of highly proficient sporting bodies (Shilling, 2008), given the continuing predominance of multi-activity sport-based curricula and the centrality of corporeal performance in sport. The symbolic assumption of ability awarded to certain body shapes and sizes (Redelius, Fagrell, \& Larsson, 2009) privileges masculinity, specifically hegemonic or dominant masculinity performed through strength, muscularity or technical competency (Bramham, 2003; Hauge \& Haavind, 2011; Parker, 1996; Tischler \& McCaughtry, 2011; Wright \& Burrows, 2006). While feminist research has traditionally given attention to girls in PE (Nilges, 2006), more recently research in pedagogy and schooling has been marked by a "boy turn” (Weaver-Hightower, 2003), and concerns about boys' struggles to negotiate discourses of the body and masculinities in school PE contexts (Drummond, 2003; Hauge \& Haavind, 2011; Kehler, 2010; Millington \& Wilson, 2010). 
Boys' bodies, it is thought, are becoming as watched as girls' (Kehler, 2010), with big consequences for those who do not perform well in sport as a marker for accepted masculinity (Tischler \& McCaughtry, 2011). Thus it could be argued that how bodies are seen and positioned influences students' learning and their (dis)engagement in PE.

Masculinity has been understood as not a singular set of characteristics and practices or a singular body type, but as multiple configurations within a hierarchy of dominant, complicit and subordinate (Connell, 1987, 2005). Connell and Messerschmidt's (2005) reconceptualisation of hegemonic masculinity considers that alternatives work to redefine hegemony. By seeing gender as a performance or something that is “done” (Butler, 1993), we acknowledge its fluidity and mutability. Mac an Ghaill's (1994) ethnography of a British secondary school provides an example of the diversity of masculine and feminine identities performed in a single institution, finding that gender identities had relational meanings as boys positioned themselves or were positioned by others as macho or academic, through their embodiment and practices. Similar research including Parker (1996) and Connell (1989) informs us that boys give different meanings to masculinity, although in any location one masculinity is thought to have dominance and put pressure on all boys, whether or not they conform. Masculinities research has shown that across the globe, as well as within institutions or various physical cultures, 'there are multiple definitions of what it means to be a man, and there are diverse ways for men to live in gender relations' (Connell, 2008: 132). Those masculinities that attain hegemonic status in any physical culture will be constituted by different physicalities, characteristics and practices. Rather than perceiving sport or physical education per se as marginalising some boys, the concept of physical culture, as localised cultural practices, discourses, or ways of being active in codes of sport, physical recreation or exercise (Hargreaves \& Vertinsky, 2001; Kirk, 1999) can contextualise explorations of practice and meaning (Silk \& Andrews, 2011). As young men engage with different physical cultures, alternative meanings or images of strong masculinity may be possible.

\section{Asian boys' bodies}

The focus of this paper is with a group of British Asian boys, those of a South Asian, specifically in this contest Indian, heritage. The meanings given to "race” or ethnicity, as well as gender, structure sport participation (Elling \& Knoppers, 2005). Sport as an institution may be concerned with maintaining hegemonic masculinity in opposition to femininity (Connell, 2005) but also with maintaining a distinction between black and white athleticism to preserve 'white superiority, white identity and forms of white, male power' (Scraton, 2001: 174). With 
the specificity of idealised masculinities being linked to white, heteronormative and muscular bodies, ethnicity and other intersections with gender must be acknowledged as contributing to the construction of ideal bodies embedded in whiteness. Whiteness has been defined as the privileging of white peoples, knowledge and experience, perceiving them as universal (Frankenberg, 1993). Not only has sporting status been associated with masculinity, but also with whiteness (Bramham, 2003; Parker, 1996) or, at other times, to blackness (Majors \& Billson, 1993), signifying that Asian and "other" bodies remain marginalised in the popular sports imagination.

Burdsey (2007: 26) notes that 'perceptions of physicality have been a common and constant source by which minority ethnic groups in general have been marginalized'. In European contexts, 'in the white imagination Asian boys were constructed as a weak masculinity' (Haywood \& Mac an Ghaill, 2003: 75). A perception of Asian young people’s low skill or submissive and frail bodies results in assumptions that they are little interested in sport, or that sporting bodies are not valued in Asian communities (McGuire \& Collins, 1998). There are few Asian sport stars (Chappell, 2001; Ismond, 2003), at least in mainstream popular sports in the UK where there has been physical and discursive marginalisation, notably in football (Burdsey, 2007; Crozier \& Davies, 2008). Although there has been little research on Asians in elite sport (Fleming, 1991; Scraton, Caudwell \& Holland, 2005), where it has been carried out, it is accused of using 'stereotypical assumptions to attribute parental constraint, religion and culture as root causes for lack of participation' (Chappell, 2001: 103). Asian boys have been seen as "below par", uncoordinated, not suited to the cold, but naturally suited to individual, especially racket, sports (critiqued by Bramham, 2003; Fleming, 1995; Johal, 2001). Bramham (2003) finds that Asian boys may be constructed by White peers as resisters, or as inferior and anti-sport, while contradictorily also dominating cricket.

Besides the impact of hegemonic masculinities, the normalising and privileging of whiteness also affects the embodied identities of young people of colour. Researching the intersectionality of gender/race/class in physical education and physical cultural engagement is crucial in understanding diverse young people's constructions of the body and self (Fitzpatrick, 2011; Flintoff, Fitzgerald, \& Scraton, 2008; Rail, 2010). Some sport sites or physical cultures may also be a place for subordinated groups of men or boys to realise a masculine identity away from white dominated physical cultures (Carrington, 1998; Fleming, 1991). Specific sites, such as Asian-only sports clubs (Bradbury, 2011), may offer spaces of resistance. For instance, Thangaraj (2010) finds American “Indo-Pak” masculine identities 
are formed in relation to blackness and not necessarily whiteness, through young men's association with basketball cultures. Considering the association of dominant masculinities with whiteness and muscularity in British physical cultures, this chapter explores the meanings of strong boys' bodies as discussed by four British Indian boys and two of their classmates (one white-Asian dual heritage and one black British) from a single-sex PE class in Year 9 (age 13-14) in an urban school with a diverse, majority-Asian student population.

\section{Visual methods}

This inquiry's design combined ethnography with participant-driven visual data. Ethnographic research can uncover the complexity of social settings, understanding that emplaced and embodied knowledge and experience is co-constructed among participants and researcher (Guba \& Lincoln, 2005; Pink, 2007). Ethnographic studies with long-term engagement in a physical education context have become common for their 'capacity ... to capture a sense of the relationship between individuals, differences between them, and their perceptions of the discourses and practices that occur in different social fields' (Hills, 2006: 544). Photo-elicitation in interviews, using participant-produced photographs (Clark, 1999) can offer alternative ways of engaging young people in sharing non-verbal embodied experiences. The turn to research with, rather than on, young people and children, that seeks to address power relations has led to greater participatory or collaborative work (Christensen \& James, 2000). The voices heard through visual methods are not perceived to be more authentic or to uncover any “truer” identity or reality (Gauntlett \& Holzwarth, 2006) than through verbal methods, but a combined verbal and visual approach may enable researchers to think differently about the experiences that are communicated by participants (Buckingham, 2009; Phoenix, 2010).

The data presented here is from a larger one-year ethnographic project with boys and girls in an ethnically-diverse secondary school in the Midlands of England that explored their discursive constructions of bodies and how this informed students' subjectivities and (dis)engagement in physical activity in and out of school. This study took place in one urban co-educational secondary school site in the East Midlands, UK. This school has a student population that is between 80 and 90 per cent minority ethnic (Ofsted, 2010). The broader project worked with 25 students, both boys and girls. During the research period (October to May) boys' PE classes involved long units of football and hockey, and shorter units of table tennis and cardio fitness in the gym. 
A number of data sources were used in this ethnographic project: field notes, group interviews, and participants' photo diaries. Researcher-produced photographs or sketches of the visual resources displayed in the PE department and school corridor notice boards provided more visual cultural context alongside field notes from PE lessons. Group interviews were carried out during school lunch break in single sex groups, to mirror the structure of the participants' PE classes and enabled discussion amongst participants (Barbour, 2007). In the first interviews, the participants discussed their experiences in physical activity and the ways bodies become admired or valued in PE. Following this, each participant was loaned a digital camera and asked to create photos recording the physical activities they engaged in over a fortnight and the people they admired in their PE class, extra-curricular club or community sports club (as spaces indicative of physical culture). Students were asked to produce around 20 photos in total and the response varied between four and 56 photos (mean = 23). The cameras were collected back and photos uploaded, printed, and reviewed by the researcher. Photo elicitation techniques advise that photos made by participants cannot be analysed alone but only alongside participants' explanations (Pink, 2007). Second and third rounds of group interviews were structured around eliciting the meanings of the participants' photos' content and the representations they offered of their experiences of physical activity during the fortnight with the camera (Clark, 1999; Harper, 2002). All visual and verbal data were coded in an inductive/deductive process. Discursive and content analyses were conducted that considered the students' meaning making in relation to bodies that have value (Wright, 2004; Rose, 2007). Among collective constructions of the meanings of strong, able or technically competent bodies, the boys negotiated their masculine identities and their participation in sporting spaces or cultures. The following section explores some of the Asian boys' (re)defining of strong male bodies in relation to their own experiences and embodiment in PE and sport. All names used in this paper are pseudonyms and distinguishing features in photographs have been blurred to protect anonymity.

\section{Findings: visualising strong bodies with boys}

Throughout the interviews questions were asked to the participants concerning the bodies that they visualised as high valued or admired within their PE class. Many boys created photos or spoke often of strong or muscular bodies, more so than bodies with technical skill or competence. Performing successful masculinity has been linked to sporting success but also 
to physicalities that express strength or muscularity (Hauge \& Haavind, 2011; Swain, 2003). A short, small-built boy, Mitesh (British Indian), explained:

Interviewer: What body types have they got?

Mitesh: Um, more big, more tall, more strong, more stronger. There are some people that are like my size and weight that um, are in the higher group [top set] but that's just to do with their ability, they're good at all that they do... Well, say if there's like a little weakling on a stick, and they go try football, people are going to just barge them out of the way. So it is about body as well.

Strong and big bodies were valued among many boys while scrawny bodies were devalued, which has been pointed out as an example of gender relationality in PE/sport discourses, where strength is masculine and weakness feminine (Hauge \& Haavind, 2011; Mac an Ghaill, 1994). Subordinate or resistant boys are still measured against mainstream or hypermasculinity (Hickey, 2008). Boys who felt that they were unable to perform sporting ability through skills instead worked to develop bodies that symbolically expressed ability or status (Redelius et al., 2010). Mitesh created photos of himself stood side by side with his best friend Satnam, a much taller, broader boy of the same age (Figure 1). Rather than feeling embarrassed to show his small frame compared to other boys', Mitesh used this photo to point out that boys gain status in $\mathrm{PE}$ through their body size and shape, not through determination, fitness or teamwork, qualities which might otherwise be considered valuable. Mitesh visualised himself as physically subordinated, with this photo. Highlighting Satnam's as an ideal body type, Mitesh explained that boys like Satnam were more likely to score goals, a key marker of status.

Frost (2003) tells us that approval from other boys is crucial and develops through displaying a valued muscular body. We can see this when Mickey (white-Asian dual heritage) and Jon (black African) discuss a photo of Ben, a tall, well-built black boy in their PE class:

Mickey: Majority of sports he's good at

Jon: He's good at football

Mickey: Everyone must be scared of him, like...

Jon: Especially in football, you just move out the way for him, even if you're in defence

Mickey: I’d go into him more! I like getting him angry, it's funny. He gets so angry.

Ben is one of the tallest boys in the class and he is often captain in football. During team games, he plays in attacking positions, a style of play that, by Ben, is rewarded. Ben is best avoided and not angered because, Mickey explains, 'he's the hardest in our year'. As Frost 
(2003: 65) says, masculine bodies are linked to 'the ability to play sports, win fights, and stand up for yourself', 'a crucial factor in identification'.

The boys' relationship with strength was complex and different body sizes and shapes were given status at different times. After discussing Ben's aggressive football style, Jon and Mickey compared his figure to that of Dev, another high status classmate, in a photo where the two boys were competing in a race on the rowing machine (Figure 2). Dev was admired for being 'hench but also skinny' (hench is slang for a muscular, toned appearance), displaying physical strength but not dominance over others in team sports, unlike Ben. During football matches in PE he was often the captain on the opposing team to Ben, but classmates were not scared of him in the same way.

The captain on the green team is Dev. As the role of captain in this football unit is to arrange team warm ups and drills before each game, the teacher often questions Dev about ways to increase the efficacy of his team's practices, such as how to increase player movement in a passing drill. Dev plays in midfield. Other boys on his team dominate play and score many of the goals. [Field notes]

Although these boys' fearful respect of their classmate Ben's aggression recalls stereotypical “angry black man” images, perceptions of Asian academicism (Bramham, 2003; Parker, 1996) and black athleticism/anti-intellectualism (St Louis, 2005), they created multiple notions of strong bodies based on themselves and their peers that resisted, while also being affected by, broader dominant masculinities (Thangaraj, 2010).

Other boys represented a strong or sporting body through pre-existing images. Harshul (British Indian) used his photos to show the posters and magazine cut outs that he had pinned to his bedroom wall. One showed his favourite cricketer, Mahendra Dhoni, who plays for the Indian national team. Dhoni is, for Harshul, 'the best batsman in the world'. Skilful but also strong, 'he can hit the ball hard'. In comparison, Harshul's football pin ups were almost all white Europeans which led him to consider that 'there are no Indian people in football... It's just you wonder like why, if they are any good'. The embodiment of footballing competence became associated for Harshul with the white footballers he saw in these posters every day. Continuing issues of both the visibility of British Asian footballers and the barriers in the sport for Asian men and women (Burdsey, 2007; Ratna, 2011; Scraton et al., 2005) were highlighted by Deepesh (British Indian) as affecting his sense of himself as a footballer and limiting his involvement in the game. He was a keen football fan but had rejected playing football outside school, choosing instead to join a boxing club. Deepesh explained that in his 'rainbow coloured' boxing club, he felt more comfortable than in football, in which he 
perceived institutional racism. He claimed that scouts from top football clubs would visit local youth teams and would not select Asian boys even if they showed sufficient talent. Through boxing, Deepesh was able to challenge notions of Asian boys as unsporty or weak. His role models in boxing were Amir Khan (British Asian) and Mike Tyson (AfricanAmerican) suggesting that, as a sport often crossing ethnic lines, his boxing participation would not be questioned as it was in football. This culture in Deepesh's boxing club enabled him to develop a sense of self as a sporty boy who could achieve success. He was keen to demonstrate his ambition to become a competitive boxer, often framing hard work in the sport as a route to success: 'like, boxing, like, if you work hard in boxing and that you can actually box for your club'. Bradbury (2011: 75) asserts that minority ethnic sports clubs offer a symbolic physical cultural space as resistance to white sporting dominance and where 'new, youthful, multi-ethnic identities' can be created.

Unlike in football, Deepesh was able to take up a masculine identity in boxing by investing in fitness training. Deepesh's photos contain a series of images of his training regime done at home and in the boxing club (Figure 3), as he worked to develop a fit body that would help his performance not just in boxing but also in PE, especially 'for the bleep test' where he felt that low fitness would be especially visible to peers. Some boys were comfortable talking about strength as something they wanted to develop and something they expected in their teammates. Deepesh, Mitesh and Mickey (who can be seen lifting weights in Figure 4) indicated their reasons for engaging in fitness or muscle-building routines outside school: 'to get hench' or to develop a body that could display competence in PE:

Like in boxing they've got all this gym stuff innit yeah, so then you can use that to tone your body (Deepesh)

When asked further questions, Mickey however seemed embarrassed to explain why he felt a need to build up muscles:

Int.: Why do you do weights?

Mickey: Oh I dunno, just because! [Laughs] Um, just what I do out of school helps me get good in school.

As in research with other schools, there were consequences for the masculine status of boys who did not perform some form of valued masculinity (Tischler \& McCaughtry, 2011; Wellard, 2006). Mickey suggests reluctance to admit to lifting weights at home yet for Deepesh, working on his body while acknowledging the need to display a competent or strong body especially in PE lessons. 
Continuing the idea that fluid constructions of strong masculinity were appropriate or inappropriate at different times, Bhagesh (British Indian) admitted that in some circumstances he felt pressure to be a 'good guy' whose appearance does not betray a rough or working class background:

Bhagesh: And like when you go for interviews. Miss, if you think about it yeah, if you have scars yeah and you go to an interview, what will they think of you?

Deepesh: They won't be interested

Bhagesh: Yeah, exactly

Deepesh: You're from a more rough environment.

Bhagesh was aware that an appearance that is identifiable with working-class physical and social status could hinder his middle-class aspirations when he looks for work. Deepesh argued back that some scars, such as from sport, are more acceptable than scars from street fighting - something he was aware of as a boxer, preparing for legitimate sporting fights. While aggression and strength were valuable on the football pitch, off the pitch similar performances of hyper-masculinity or toughness were much less valuable in relation to embodying "good guy". Some boys discussed how sport and physical activity 'gets us off the streets', recalling discourses of troublesome working class masculinity or the risk of becoming a victim of violence. Bhagesh and Deepesh did not in fact carry the scars they were so worried about, but they demonstrated how aware they were of the classed and racialised boundaries of young manhood that structured their lives, informed by the economic positions of the city's Asian populations, providing the discourses they could use to narrate their experiences. As Fleming (1991) argues, even where Asian and Black British boys and masculinities constitute a majority and are dominant in school spaces or physical cultures, there are multiple practices and performances through which they produce their selves and others so that it is not possible to find a singular narrative of the physicalities of British Asian boys. While some boys may be marginalised in some physical cultures because of their ethnicity (Brah, 1996), as Deepesh indicated in football, there are complex intersections of ethnic categories with class, age, body size and gender relations.

\section{Discussion}

Considering boys' representations and meaning-making, this paper has examined a number of elements of racialised performances and narratives of masculinity, through meanings given to strength and size. Their embodied knowledges as British Indian teenage boys inform their self constructions in relation to hegemonic masculinities both within their school and of 
mainstream British boyhood. Through reading their own and others' bodies, boys understand how they must develop a strong and skilled body to have status not only as a sporting body but as a boy (Kehler, 2010; Swain, 2003). There remained pressure to embody valued versions of masculinity as we saw the boys working to develop their muscularity outside school to benefit their performances in PE, but what valued masculinity looks like varied, being informed by intersections with class and ethnicity (Connell \& Messerschmidt, 2005; Swain, 2003). Through PE, extra-curricular clubs and informal play, school can be a place where young Asians 'have the opportunity to formulate their own realities of sport and physical activity’ (Fleming, 1991: 31). Precisely because of tension at the boundaries in relation to subordinate/alternative masculinities and femininities, there is possibility to create resistance to hegemonic or hypermasculinity defined through whiteness and success in football. The boys often chose to join sports clubs or take up recreational activities where the culture was inclusive and supported their sense of self.

These boys valued different bodies and behaviours in different sports, indicating that teachers' and researchers' understanding of the ideal masculine sporting body as muscular and competent in games (Millington \& Wilson, 2010; Parker, 1996; Tischler \& McCaughtry, 2011) could be broadened to account for complex localised cultures and young people's understandings of their experiences in the spaces between dominant narratives (Rail, 2009). In a school or physical culture that was not numerically or symbolically dominated by white masculinities, these British Asian boys were more able to define their masculinities as resisting but in reaction to whiteness as dominant (Connell, 1995; Thangaraj, 2010). They resisted the construction of British Asian boys as weak or unsporty (Bramham, 2003; Burdsey, 1997; Fleming, 1991). The boys valorised black and Asian muscular bodies and found spaces or physical cultures in which to have positive experiences of physical activity. O'Donnell and Sharpe (2000: 80) indicate that the Asian boys they researched 'rarely drew on [stock cultural knowledge and referents of Asians] in a way which crudely endorsed dominant stereotypes' but were aware of assumptions about physicality and activity preference in the way they shaped their subjectivities. Hauge and Haavind (2011) point out that discourses about male bodies are recognised by all boys, but "deployed" in different ways, intersecting with other discourses such as those of age and ethnicity. As Deepesh's feelings about football indicate, within broader social structures Asian boys' opportunities to be involved in sports are still mediated by their positions at the margins (Martino \& PallottaChiarolli, 2003), as “different” boys. Worried about looking rough or tough, the boys were 
still framed by boundaries of respectable masculinity that intersect with ethnicity and class (O’Donnell \& Sharpe, 2000). Connell and Messerschmidt (2005) inform us that it is important to understand the interplay between local, regional and global masculinities. Physical culture enables us to conceptualise corporeal practices that vary across codes of sport, physical recreation and exercise for contextualised explorations to be made. These students wanted to be strong or muscular for a number of reasons: to assist in being seen as technically competent or fit, or merely because the appearance of a muscular body brought status in some circumstances. They resisted dominant notions of Asian boys as weak while reproducing strength in competitive sport as a key marker of masculinity. Within their perceptions of certain physical cultures, particularly football, whiteness remains dominant (Burdsey, 2007).

\section{Educational implications}

This work is part of a broader study that engaged young people in visual and verbal data production to investigate their physical activity practices within the cultures of their school and community. The PE classroom can be a site for empowerment through knowledge of the body, providing opportunities for young people to construct their own meanings of their identities and deconstruct dominant notions of sporting or ideal bodies (Armour, 1999). Photography or related tasks such as scrapbooking and poster-making can provide ways to begin conversations about young people's consumption of images, the meanings they give to different bodies, and how role models are formed and perceived, as a research or as curricular tasks (Krane et al., 2011; Oliver, 2001). Participatory photography in ethnographic inquiry can constitute a less intrusive way of accessing out of school experiences and likewise, can show us what we do not see of students' physical culture engagement both in and out of school, if student-participants grant this visual access to their wider worlds (Clark-Ibáñez, 2007). These boys shared photos of posters they had pinned on their bedroom walls that gave a sense of the visual culture they are surrounded by every day. With images of, for instance, Mahendra Dhoni and Mike Tyson, photo elicitation opened up conversation, in Harshul's and Deepesh's group interviews respectively, around the representation and embodiment of minority ethnic sport stars both in media and in sports as a whole (Wright, 2004). Furthermore, creating photos enabled participants to share concepts that they did not want to or were unable to verbalise, as Mickey’s self-representation in Figure 4 illustrates. 
The visual might potentially be used as a tool for raising critical questions in schools about issues of masculinity and race/ethnicity in certain sports that still permeate boys' construction of the body and identity. These boys used their photographs to compare and analyse their experiences and notions of what a sporting or strong body can be, and by looking at and listening to other boys' visual narratives were able to reflect on their assumptions and practices. In particular, Mitesh’s photos (including Figure 1) and his explanations in a group interview provided a site that was at times difficult for his group mates as together they reassessed their contributions to a culture in PE that enabled boys like Mitesh to feel physically marginalised. Visual methods can help educators and researchers to see the ways young men 'are physically positioned within a repertoire of masculine codes that are read off and enacted by the body' (Kehler, Davison \& Frank, 2005: 64). The boys' masculine subjectivities intersected with their negotiations of safe or successful spaces for minority ethnic young people in physical culture. The research suggests that attention needs to be paid to the way ethnicity is made visible or invisible in researching masculinities and bodies. We can work with boys - and all young people - by thinking through, discussing and imagining alternative ways of visualising strong masculinities. In both teaching and researching gender experiences in PE, intersections with race/ethnicity as well as age or class play a role in how gender identities are conceived, performed and experienced. 


\section{Bibliography}

Armour, K. M. (1999). The case for a body focus in education and physical education. Sport, Education and Society, 4(1), 5-15.

Barbour, R. (2007). Doing focus groups. London: Sage.

Bradbury, S. (2011). Racisms, resistance and new youth inclusions: the socio-historical development and shifting focus of black, Asian and minority ethnic football clubs in Leicester. In D. Burdsey (ed.). Race, ethnicity and football: persisting debates and emergent issues. Abingdon: Routledge.

Brah, A. (1996). Cartographies of diaspora: contesting identities. London: Routledge.

Bramham, P. (2003). Boys, masculinities and PE. Sport, Education and Society, 8(1), 57-71.

Buckingham, D. (2009). 'Creative' visual methods in media research: possibilities, problems and proposals. Media, Culture \& Society, 31(4), 633-652.

Burdsey, D. (2007). British Asians and football: culture, identity, exclusion. Abingdon: Routledge.

Butler, J. (1993). Bodies that matter: on the discursive limits of 'sex'. New York and London: Routledge.

Carrington, B. (1998). Sport, masculinity, and black cultural resistance. Journal of Sport and Social Issues, 22(3), 275-298.

Chappell, B. (2002). Race, ethnicity and sport. In A. Laker (Ed.). The sociology of physical education and sport. London: RoutledgeFalmer.

Christensen, P. and James, A. (2000). Childhood diversity and commonality: some methodological insights. In P. Christensen and A. James (Eds.), Research with children: perspectives and practices. London: Falmer Press.

Clark, C. D. (1999). The autodriven interview: a photographic viewfinder into children's experience. Visual Sociology, 14(1), 39-50.

Connell, R.W. (1989). Cool guys, swots and wimps: the interplay of masculinity and education. Oxford Review of Education, 15(3), 291-303.

Connell, R.W. (1995) Masculinities (2nd ed.). Cambridge: Polity Press.

Connell, R. (2008). Masculinity construction and sports in boys' education: a framework for thinking about the issue. Sport, Education and Society, 13, 131-145.

Connell, R. W., \& Messerschmidt, J. W. (2005). Hegemonic masculinity: rethinking the concept. Gender \& Society, 19(6), 829-859. 
Crozier, G., \& Davies, J. (2008). “The trouble is they don't mix': self-segregation or enforced exclusion? Race Ethnicity and Education, 11(3), 285-301.

Drummond, M. (2003). The meaning of boys' bodies in physical education. The Journal of Men's Studies, 11(2), 131-143.

Elling, A., \& Knoppers, A. (2005). Sport, gender and ethnicity: practises of symbolic inclusion/exclusion. Journal of Youth and Adolescence, 34(3), 257-268.

Fleming, S. (1991). Sport, schooling and Asian male youth cultures. In G. Jarvie (Ed.), Sport, racism and ethnicity. London: Falmer Press.

Flintoff, A., Fitzgerald, H., \& Scraton, S. (2008). The challenges of intersectionality: researching difference in physical education. International Studies in Sociology of Education, 18(2), 73-85.

Gauntlett, D., \& Holzwarth, P. (2006). Creative and visual methods for exploring identities. Visual Studies, 21(1), 82-91.

Gorely, T., Holroyd, R., \& Kirk, D. (2003). Muscularity, the habitus and the social construction of gender: towards a gender-relevant physical education. British Journal of Sociology of Education, 24(4), 429-448.

Guba, E. and Lincoln, Y.S. (2005). Paradigmatic controversies, contradictions, and emerging confluences. In N.K. Denzin and Y. S. Lincoln (Eds.) Handbook of qualitative research (3rd ed.). London: Sage.

Harper, D. (2002). Talking about pictures: a case for photo elicitation. Visual Anthropology, 17(1), 13-26.

Hauge, M.-I., \& Haavind, H. (2011). Boys' bodies and the constitution of adolescent masculinities. Sport, Education and Society, 16(1), 1-16.

Haywood, C. \& Mac an Ghaill, M. (2003). Men and masculinities. Buckingham: Open University Press.

Hickey, C. (2008). Physical education, sport and hyper-masculinity in schools. Sport, Education and Society, 13(2), 147-161.

Hills, L. (2006). Playing the field(s): an exploration of change, conformity and conflict in girls' understandings of gendered physicality in physical education. Gender and Education, 18(5), 539-556.

Ismond, P. (2003). Black and Asian athletes in British sport and society: a sporting chance? Basingstoke: Palgrave Macmillan.

Johal, S. (2001). Playing their own game: a South Asian football experience. In B. Carrington and I. McDonald (Eds.). 'Race', sport and British Society. London: Routledge. 
Kehler, M. (2010) Negotiating masculinities in PE classrooms: boys, body image and "want[ing] to be in good shape". In M. Kehler and M. Atkinson, (Eds.). Boys' bodies: speaking the unspoken. New York: Peter Lang.

Kehler, M.D., Davison, K. \& Frank, B. (2005). Contradictions and tensions of the practice of masculinities in school: interrogating "good buddy talk". Journal of Curriculum Theorizing, 21(4), 59-72.

Krane, V., Ross, S. R., Miller, M., Ganoe, K., Lucas-Carr, C., \& Barak, K. S. (2011). “It’s cheesy when they smile": what girl athletes prefer in images of female college athletes. Research Quarterly for Exercise and Sport, 82(4), 755-768.

Mac an Ghaill, M. (1994). The making of men: masculinities, sexualities and schooling. Oxford: Open University Press.

Majors, R. \& Billson, J. (1993). Cool pose: the dilemmas of black manhood in America. New Yotk: Simon \& Schuster.

McGuire, B., \& Collins, D. (1998). Sport, ethnicity and racism: the experience of Asian heritage boys. Sport, Education and Society, 3(1), 79-88.

Millington, B. \& Wilson, B. (2010). Consuming media, constructing masculinities: a study of youth audiences and physical education in "reflexively modern" times. In M. Kehler and M. Atkinson (eds.). Boys' bodies: speaking the unspoken.. New York: Peter Lang.

Mirza, H. S. (2009). Plotting a history: Black and postcolonial feminisms in "new times." Race Ethnicity and Education, 12(1), 1-10.

O’Donnell, M. \& Sharpe, S. (2000). Uncertain masculinities: youth, ethnicity and class in contemporary Britain. London: Routledge.

Ofsted. (2010). School inspection report. Ofsted. Retrieved 5 June 2012, from http://www.ofsted.gov.uk/inspection-reports/find-inspection-report.

Oliver, K.L. and Lalik, R. (2000). Bodily knowledge; Learning about equity and justice with adolescent girls. New York: Peter Lang.

Oliver, K.L. (2001). Images of the body from popular culture: engaging adolescent girls in critical inquiry. Sport, Education and Society, 6(2), 143-164.

Parker, A. (1996). The construction of masculinity within boys' physical education. Gender and Education, 8(2), 141-158.

Phoenix, C. (2010). Seeing the world of physical culture: the potential of visual methods for qualitative research in sport and exercise. Qualitative Research in Sport and Exercise, 2(2), 93-108.

Pink, S. (2007). Doing visual ethnography: images, media and representation in research. London: Sage. 
Prosser, J. (2007). Visual methods and the visual culture of schools. Visual Studies, 22(1), 1330.

Rail, G. 2009. Canadian youths' discursive constructions of health in the context of obesity discourse. In J. Wright and V. Harwood (Eds.).Biopolitics and the 'obesity epidemic': governing bodies. 141-156. Abingdon: Routledge.

Redelius, K., Fagrell, B., \& Larsson, H. (2009). Symbolic capital in physical education and health: to be, to do or to know? That is the gendered question. Sport, Education and Society, 14(2), 245-260.

Rose, G. (2007). Visual methodologies: an introduction to the interpretation of visual materials. London: Sage.

Scraton, S., Caudwell, J., \& Holland, S. (2005). "Bend it like Patel”: centring "Race”, ethnicity and gender in feminist analysis of women's football in England. International Review for the Sociology of Sport, 40(1), 71-88.

Shilling, C. (2008). Changing bodies: habit, crisis and creativity. London: Sage.

Silk, M. L. \& Andrews, D. L., 2011. Toward a Physical Cultural Studies. Sociology of Sport Journal, 28 (1), 4-35.

St Louis, B. (2005). Brilliant bodies, fragile minds: race, sport and the mind/body split. In C. Knowles and C. Alexander (Eds.). Making race matter: bodies, space and identity. Basingstoke: Palgrave Macmillan.

Swain, J. (2003). How young schoolboys become somebody: the role of the body in the construction of masculinity. British Journal of Sociology of Education, 24(3), 299314.

Swain, J. (2006). The role of sport in the construction of masculinities in an English independent junior school. Sport, Education and Society, 11(4), 317-335.

Thangaraj, S. (2010). Ballin’ Indo-Pak style: pleasures, desires, and expressive practices of "South Asian American" masculinity. International Review for the Sociology of Sport, 45(3), 372-389.

Tischler, A., \& McCaughtry, N. (2011). PE is not for me: when boys' masculinities are threatened. Research Quarterly for Exercise and Sport, 82(1), 37-48.

Wellard, I. (2006). Able bodies and sport participation: social construction of physical ability for gendered and sexually identified bodies. Sport, Education and Society, 11, 105119.

Weaver-Hightower, M. (2003). The "boy turn" in research on gender and education. Review of Educational Research, 73(4), 471-498. 
Wright, J. E. (2004). Analysing sportsmedia texts: developing resistant reading positions. In J. E. Wright, D. Macdonald \& L. Burrows (Eds.), Critical inquiry and problemsolving in Physical Education. London: Routledge.

Wright, J. \& Burrows, L. (2006). Re-conceiving ability in physical education: a social analysis. Sport, Education and Society, 11(3), 275-291.

\section{Figures}

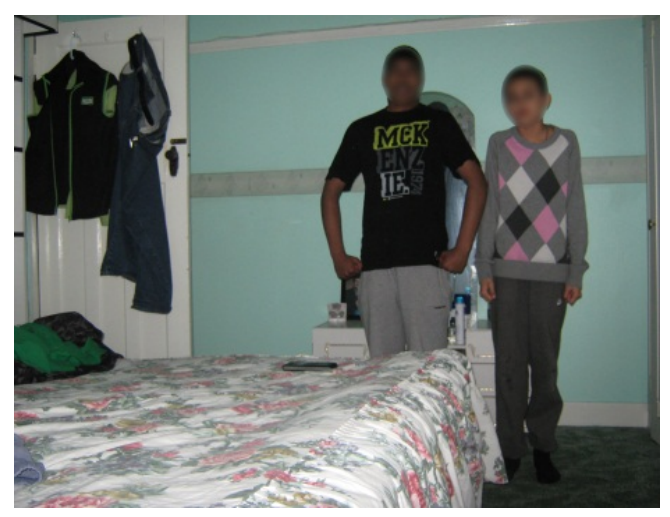

Figure 1 Satnam and Mitesh: "it shows the diversity between stockier build and skinnier build"

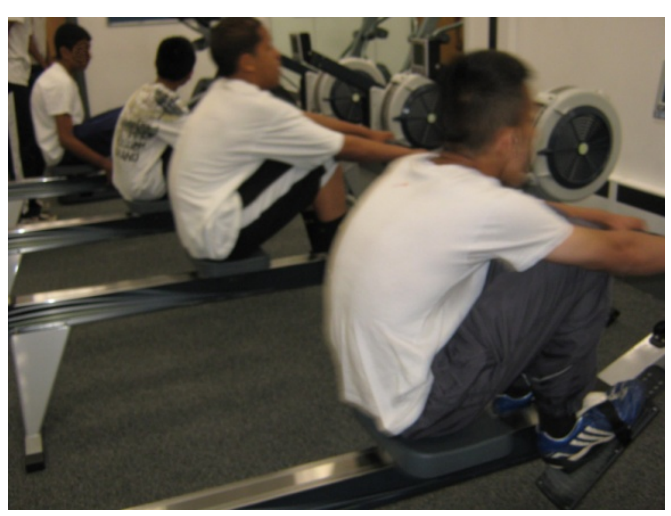

Figure 2 Ben and Dev on the rowing machines 


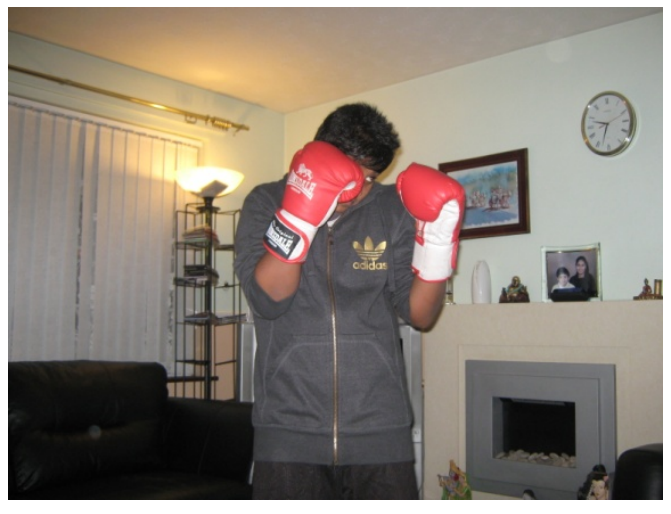

Figure 3 Deepesh's training regime

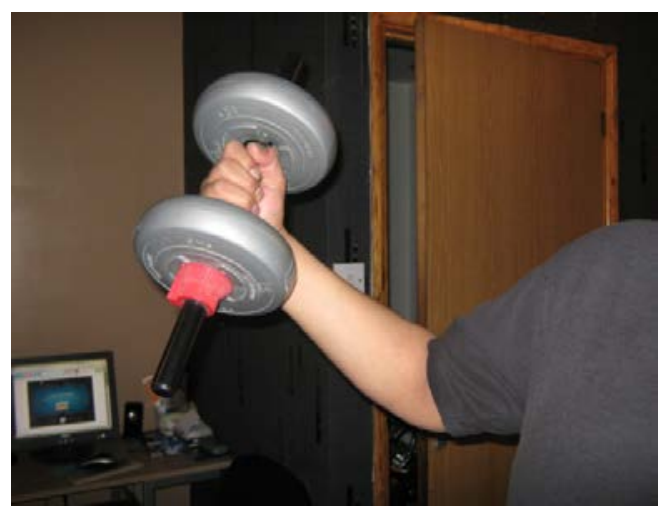

Figure 4 Mickey lifting weights 